\title{
The Restoration and Conservation of Islamic Monuments in Egypt
}

\author{
Edited by Jere L. Bacharach. Cairo: The American Univer- \\ sity in Cairo Press, 1995, ix $+194 \mathrm{pp}$.
}

This book is about the care of the Islamic architectural heritage in Egypt. The book's salient ideas amount to an argument for the necessity of care based on the implied quality of significance attached to monuments and urban districts as material testimonies to the country's history and culture through successive Islamic periods. The argument is supported by a series of papers dealing with the causes of physical deterioration of these testimonies and the strategies and procedures for preserving them.

That existing buildings endure deterioration in their structural and material integrity over time poses no question. Familiar climatic elements, such as temperature and humidity, as well as normal use, dictate an incessant rate of deterioration. But eminent dangers, especially for historic buildings, stem from the oppressive acts of humans and nature. Widespread industry, population growth, land development, and wars all contribute to human-generated building threat and deterioration; floods, hurricanes, and earthquakes, on the other hand, spearhead a gamut of natural forces of building deterioration.

Relishing the value of architectural heritage and recognizing the need for its protection have prompted many nations to develop plans and programs of protection. To clarify issues crucial to protection efforts, debate intensified, particularly in Western Europe and the United States, since the early years of the twentieth century. These issues revolved around such sweeping questions as why (rationale), what (scope), and how (means and methods) to protect historic buildings. The "why" debate resolutions shaped the philosophy of preservation, and such a philosophy shaped, in turn and at least in principle, the answers for the "what" and "how" questions.

Architectural heritage protection endeavors entered the intemational arena during the 1960s. Worldly conventions, charters, and organizations came into existence in order to foster cooperation between world members in the area of preservation. This situation presented opportunities, often for the first time, for developing countries to initiate or strengthen preservation efforts at home. These opportunities were enhanced through programs of international bodies, such as the United Nations Educational, Scientific, and Cultural Organization (UNESCO) and the International Council on Monuments and Sites (ICOMOS). However, opportunities to strengthen 
preservation efforts also benefited from sympathetic organizations whose endeavors crossed their national borders to support preservation projects in other countries. A significant part of the book describes preservation projects that received this kind of support.

The Restoration and Conservation of Islamic Monuments in Egypt is an anthology of conference essays on a variety of preservation facets concerning Egypt's Islamic monuments. The book is, unfortunately, the child of a drastic event in Egypt: the earthquake on 12 October 1992. A conference was held during 12-15 June 1993 at the American University in Cairo to assess the earthquake's aftermath and to discuss preservation possibilities. The conference was sponsored by the American Research Center in Egypt, the Egyptian Antiquities Organization, and the Getty Conservation Institute. This book reflects the multidisciplinary expertise of conference contributors, among whom were art historians, archaeologists, administrators, architects, and engineers.

The book comprises fifteen papers from the conference, supportive conference remarks, conference resolutions, contributor information, and an index. The papers are organized under the major headings "Restoration" and "Conservation." However, in the body of the book, these headings are not marked anywhere to signify the categories of papers they accommodate. The difficulty the editor declared in classifying some essays under restoration or conservation is a genuine claim because, borrowing from the Preface, "many of the articles on restoration include important information on conservation, and vice versa." But, the underlying meanings of restoration and conservation themselves are not rendered, thus leaving the reader, particularly the nonspecialist, without a guiding frame of reference. The papers cover problems and methods of intervention for historic monuments from the Fātimid, Ayyūbid, Mamlūk, and Ottoman periods. Such coverage accords well with the book's title descriptor "Islamic Monuments," but not with the "in Egypt" phrase, since most essays and project descriptions involve buildings and districts in Cairo rather than in Egypt at large.

The architectural heritage protection questions of why, what, and how present a tempting framework for assessing the "evenness" of the subject matter. In this light, the subject matter on issues pertinent to the three questions reveals imbalance. The book's diminutive philosophical arguments for preservation contrast with a lengthy array of preservation methodological descriptions. In this vein, Irene A. Bierman's enlightening philosophical essay, "Urban Memory and the Preservation of Monuments," is dwarfed in the face of a considerable number of pure technology and engineering treatments, such as the "Structural Aspects of Damage to Islamic Monuments" by A. A. Abdel Gawad, M. S. Hilal, and M. Abou Kefa and Giorgio Croci's "Safety Evaluation and Restoration Techniques of Islamic Monuments." Furthermore, the book's methodical descriptions themselves exhibit an imbalance, since the economic, organizational, and legal measures of preservation receive only scant exposure. 
The scholarly stance that writers take in developing their essays differs. While several produced erudite essays, the majority seem to have relied solely on their technical expertise, especially practical experience gained from the project at hand, to bring out their contributive piece. Erudite writing shows in such essays as Bierman's, Abd El-Zaher A. Abo El-Ela's “The Impact of Environmental Pollution on the Mosque of al-Azhar and the Complex of al-Ghuri," Phillip Speiser's "The Egyptian-German Restoration of Darb al-Qirmiz, Cairo," and Saleh Lamei's "Restoration of the Mosque of al-Zahir Baybars in Cairo." The technical expertise-based writing, however, reflects eloquently in some descriptive and analytical essays such as "Priorities in Selecting Restoration Sites: An Urban-Conscious Approach," by Ahmed S. Ouf and "The Preservation and Retrofit of Islamic Monuments in Cairo after the Earthquake of 12 October 1992," by David W. Look.

Beyond observations at the level of a specific essay, issue, or preservation project, the book raises a number of high-order concerns associated with protecting historic monuments and sites in developing countries in general and in Islamic countries in particular. Some of these concerns, which may or may not have been communicated directly in the book, are represented here in question form:

1. Perceiving the immense magnitude of historic architecture in countries such as Egypt, Iran, or Turkey, how can the meager financial and technical resources available be reconciled with the colossal needs for protection?

2. Recognizing the benefits that can be reaped from international cooperation, in what fashion could such cooperation be best utilized to develop a domestic base of knowledge and expertise that, for obvious reasons, would have a lasting impact on national preservation programs and policies?

3. Acknowledging the significance of the humanities and the social sciences in formulating national philosophies of preservation, what can be done to support the scholarly and participatory role of specialists in these fields to strengthen policies and programs of heritage protection?

4. Admitting that the generalized use of the term Islamic can be vague, how can this term be articulated enough for architectural heritage purposes both on the principles (philosophy and policy) and the practical levels?

A paramount message that The Restoration and Conservation of Islamic Monuments in Egypt conveys is that the increasingly deteriorating architectural heritage of that country, although it may benefit from international preservation support, will essentially benefit from in-house indigenous programs and policies. The sway of the book's subject matter toward 
preservation methodology and away from philosophical principles does not obscure the readability and credibility of the message. Nor does the choice of the essays' authors to take a purely scholarly or expertise-based stance of exposition. Due to the situational commonalities among many developing and Islamic countries, as can be read from the high-order concerns previously stated, the book's message has far-reaching implications. The book is a worthwhile piece of literanue.

Salim A. Elwazani Architecture/Environmental Design Program Department of Visual Communication and Technology Education Bowling Green State University Bowling Green, Ohio 